University of New Hampshire

University of New Hampshire Scholars' Repository

$11-2007$

\title{
Climate, fishery and society interactions: Observations from the North Atlantic.
}

Lawrence C. Hamilton

University of New Hampshire, lawrence.hamilton@unh.edu

Follow this and additional works at: https://scholars.unh.edu/soc_facpub

Part of the Sociology Commons

\section{Comments}

This is an Author's Original of an article published by Elsevier in Deep-Sea Research Part II: Topical Studies in Oceanography in 2007, available online: https://dx.doi.org/10.1016/j.dsr2.2007.08.020. This manuscript version is made available under the CC-BY-NC-ND 4.0 license http://creativecommons.org/licenses/by-nc-nd/4.0/

\section{Recommended Citation}

Hamilton, L.C. Climate, fishery and society interactions: Observations from the North Atlantic. (2007) Deep-Sea Research Part II: Topical Studies in Oceanography, 54 (23-26), pp. 2958-2969.

This Article is brought to you for free and open access by the Sociology at University of New Hampshire Scholars' Repository. It has been accepted for inclusion in Sociology Scholarship by an authorized administrator of University of New Hampshire Scholars' Repository. For more information, please contact Scholarly.Communication@unh.edu. 
AUTHOR'S DRAFT. Final version published at:

Hamilton, L.C. 2007. "Climate, fishery and society interactions: Observations from the North Atlantic.” Deep Sea Research II 54:2958-2969. doi: 10.1016/j.dsr2.2007.08.020

\title{
CLIMATE, FISHERY AND SOCIETY INTERACTIONS OBSERVATIONS FROM THE NORTH ATLANTIC ARC
}

Lawrence C. Hamilton

University of New Hampshire

Durham, NH 03824

e-mail: Lawrence.Hamilton@unh.edu

fax: $1-603-862-3558$

Acknowledgments: The North Atlantic Arc (NAArc) research project has been supported by grants from the Arctic System Science and Arctic Social Sciences programs of the U.S. National Science Foundation (OPP-9515380 and OPP-9912004).

\begin{abstract}
KEYWORDS

Fisheries collapse, social impacts, social change, human dimensions, demographics, Atlantic cod, Atlantic herring
\end{abstract}

\section{INTRODUCTION}

When a fishery declines abruptly, we ask about the causes and impacts. Both have complex social dimensions. Overfishing, environmental variation and species interactions are the usual-suspect causes, and sometimes all present at the scene of the crime. Disentangling their effects, or even just blaming one, presents an attractive goal because the perceived cause will have implications for what the government response should be, including future regulation and compensation for lost income. Environmental variation or species interactions tend to be less socially threatening explanations than overfishing. Overfishing implies that government and/or fishers are at fault. Scientifically choosing between competing explanations proves difficult, however. When fishing spikes and environmental downturns occur close together in time, our datasets rarely provide information enough to quantify their separate effects. Moreover, the real dynamics almost certainly are not linear or in just one direction. Fisheries affect fish populations in ways likely to increase their vulnerability to environmental variation - by removing, for example, many of the large, older fish that are individually and reproductively more robust. They selectively thin out certain predators or prey, with effects that could harm or benefit other species (or other life stages of the same species) throughout the food web, moving an ecosystem toward new states or less stability.

Just as fisheries impacts on marine ecosystems are confounded by environmental variation, so the impacts of fisheries events on society are confounded by other technological, cultural, political and economic forces. Careful analysis is required here as well. Interdisciplinary, comparative studies, with attention to the timing of environmental and social 
changes, prove helpful for understanding their interactions. This paper draws on findings from one such study, the North Atlantic Arc project, which over 1996-2005 examined fishing communities of Newfoundland, Greenland, Iceland, the Faroe Islands and Norway. During the last third of the 20th century those regions experienced broad ecological and environmental changes including the collapse of two of the richest fisheries on earth-Northeast Atlantic herring (Clupea harengus) in the late 1960s, and Northwest Atlantic cod (Gadus morhua) in the early 1990s. Some general patterns in environment-society interactions were observed across these disasters, and the diverse societies they involved.

\section{NORTHWEST ATLANTIC COD}

NW Atlantic cod illustrate the negative synergy of environmental adversity coming atop overfishing. West Greenland stocks (first graph in Figure 1) were reduced by peak overfishing in the early to mid-1960s. The fall after this peak coincided with the abrupt arrival in 1969-70 of a pulse of cold, fresh Arctic water - the Great Salinity Anomaly of the 1970s (GSA'70s; see Dickson et al., 1988). Although warmer conditions eventually returned to West Greenland, they were punctuated by further salinity anomalies related to circulation changes and Greenland Ice Sheet attrition (Belkin et al., 1998; Belkin, 2000) that created conditions off West Greenland periodically too cold for local spawning. Moreover, wind and North Atlantic Oscillation (NAO) related shifts in flow of the Irminger Current resulted in fewer cod being imported from Icelandic waters (Buch, 2000; Buch et al., 2001). After a small terminal spike in fishing, 1988-90 (mainly catching a cohort brought by the Current in one good year, 1984), Atlantic cod virtually disappeared from West Greenland. Several other demersal species had declined steeply as well (Rätz 1992, 1999). After cod declined, northern shrimp (Pandulus borealis) became more abundant, a trophic-level shift consistent with Pauly et al.'s (1998) description of "fishing down food webs." An emerging shrimp fishery took the place of cod as Greenland's economic staple (Hamilton et al., 2000a, 2003; Rasmussen \& Hamilton, 2001).

\section{$<<$ Figure 1 about here $>>$}

The famous 1990s collapse of Newfoundland's cod fishery (2nd, 3rd and a share of the 4th graph in Figure 1) followed a similar pattern of overfishing compounded by adverse climate, near-disappearance of the dominant species, then a new ecological and economic prominence for crustaceans. Biological analyses point to overfishing, first by international fleets in the postwar years, then after 1977 mainly by Canadian vessels, as the primary cause of the cod collapse (Hutchings \& Myers, 1994; Sinclair \& Murawski, 1997). Climate was a substantial contributing factor, however (Drinkwater, 2002). Unusually cold, icy waters off east, north and northwest Newfoundland in the late 80s and early 90s reflected some of the same NAO/wind and salinity anomalies that beset the final years of Greenland's cod fishery. Newfoundland's collapse became official with moratoria on cod fishing in 1992 and 1994, after most of the fish were gone. Cod abundance, size-at-age and catches had began falling earlier, at least since the mid-80s peak in catches that Palmer and Sinclair's (1997) northwest Newfoundland fishermen described as their "glory years." Off Newfoundland as off Greenland, the decline involved other species besides cod (Sinclair and Murawski, 1997; Lambert \& Dutil, 2000), and appeared to precipitate a trophic shift that left invertebrates - especially snow crab (Chionoecetes opilio) and lobster (Homarus americanus), as well as northern shrimp - the new staples in reorganized fisheries (Hamilton and Butler, 2001; Hamilton et al., 2004a). 


\section{NORTHEAST ATLANTIC HERRING}

A collapse of similarly great ecological and human scale had occurred a few decades earlier in herring fisheries of the NE Atlantic. Figure 2 depicts catches of Norwegian springspawning herring, the main stock of the Atlanto-Scandian complex. This vast migratory resource had intermittently supported coastal fisheries off Norway for centuries, and played a major role in Iceland's 20th-century journey from poverty to independence and affluence. Intensified fishing effort drove international catches erratically upwards over the middle years of the century, until they reached a sharp unsustainable peak, like the cod fisheries of Figure 1, in the 1960s. The 1960s peak clearly reflected capture efficiency, driven by technology and markets, rather than fish abundance - spawning stock biomass had been declining since at least 1950, under heavy fishing pressure throughout the herring's life cycle and migratory range (ICES, 2001).

$<<$ Figure 2 about here $>>$

During the 1950s and early 60s, herring became less available on traditional nearshore grounds. The rising catches were captured instead by an industrialized fishery that could pursue shrinking stocks farther out to sea. Unlike the cod fisheries, the 1960s herring-catch peak was followed immediately by a total collapse, as a killer spike of fishing coincided with the late-60s arrival of cold, low-salinity Arctic water on feeding grounds north of Iceland (Vilhjálmsson 1997). This Arctic ice and surface water pulse, driven south through Fram Strait by strong NAOassociated winds, was the first sighting of GSA'70s, "one of the most persistent and extreme variations in global ocean climate yet observed in this century" (Dickson et al., 1988:103). Cold fresh surface water curtailed phytoplankton blooms, depriving zooplankton and hence the herring of food (Thórdardóttir, 1977; Ástthórsson et al., 1983; Ástthórsson and Gíslasson, 1995, 1998). Herring catches fell two orders of magnitude, and could not begin to recover for more than two decades. Rising stocks of capelin (Mallotus villosus), and more recently crustaceans, eventually became a partial economic substitute for the absent herring, but the labor-intensive "herring adventure" was over, and many former herring towns in Iceland and Norway, like the Newfoundland cod outports, declined (Hamilton et al., 2004b, forthcoming-a).

Figures 1 and 2 portray two great Atlantic disasters, involving unrelated fish stocks in different niches, ecosystems and decades, and on opposite sides of the ocean. They nevertheless have several patterns in common: (1) spikes of depletion by industrialized fishing fleets in the postwar years, leading to steep declines by the early 1970s; (2) complete, multi-decade collapse when a fishing spike (in cod's case, the secondary 1980s peak) coincided with adverse, largescale climatic events; and (3) ecosystem and hence fisheries reorganization, where low-trophiclevel species expanded after the main fisheries targets (and in the NW Atlantic, many bystander species) declined.

Each fisheries story has unique details, as becomes even clearer at disaggregated levels. For example, the herring adventure unfolded quite differently for individual herring towns of north and east Iceland (Hamilton et al., forthcoming-a), or for different age groups, genders and families within each town. The outlines above merely highlight broad patterns. Although related $\mathrm{NAO/global} \mathrm{climate} \mathrm{events} \mathrm{(the} \mathrm{salinity} \mathrm{anomalies,} \mathrm{manifestations} \mathrm{of} \mathrm{increasing} \mathrm{fresh-water}$ export from the Arctic) appear in each of these stories, their other strong connection is human.

For a view showing the human connection alone, Figure 3 depicts herring catches in the NW Atlantic, off the coast of New England states Massachusetts, New Hampshire and Maine. This plot displays the same technology and market-driven 1960s killer-spike pattern we saw in 
Figures 1 and 2. As with the previous examples, the downturn deepened because catches fell less rapidly than stocks, leading to much higher mortality rates. Estimated biomass by the early 1980s stood around 5\% of its 1965 level. In the milder New England climate, no comparably harsh environmental conditions compounded the overfishing. Even so, herring biomass did not regain its 1965 level until 1995.

$<<$ Figure 3 about here $>>$

\section{HUMAN POPULATIONS RESPOND TO CRISIS}

Fisheries declines threaten the income of fishers, processors and fisheries-dependent communities. Newfoundland's cod crisis, for example, was widely reported to have cost 40,000 people their jobs. Loss of fisheries income has secondary effects on the non-fishing economy, on government policies and, less obviously, across a range of social indicators such as migration, education, dependency and population age structures. Ecological changes at sea thus influence social-ecological changes on land. From the North Atlantic Arc case studies, some general observations emerged about the human dimensions of ecological change.

Outmigration by young adults can happen rapidly, and change the places left behind. Net outmigration involving relatively mobile individuals - young adults, women, the most educated and skilled - has been observed in connection with recent fisheries troubles in Newfoundland, Greenland, Iceland, Norway and the Faroe Islands (e.g., Hamilton and Otterstad 1998a; Hamilton and Butler 2001; Hamilton et al. 2004a, 2004c). When fisheries decline, outmigration becomes one of the first adaptive choices seen by individuals, or considered as a family strategy. At the same time, outmigration reduces adaptive possibilities for the communities they leave behind. Migration affects almost every social dimension. The population contracts, turns older and sometimes becomes more male (Hamilton and Otterstad 1998b; Hamilton et al. 2004c). Median family size and birth rates decline, reflecting the depature of young adults and families as well as changing socioeconomic realities. Certain other indicators such as crime or divorce rates - classically viewed, in social-impacts research, as measures of distress - might actually improve as young people depart (Hamilton and Butler, 2001). Departure of educated (or collegebound) individuals diminishes a community's human capital, making successful economic diversification more difficult. The proportion depending on government tends to increase (Hamilton and Butler, 2001; Hamilton et al., 2004a).

Figure 4 illustrates the population changes in Newfoundland's four most fisheriesdependent regions over 1966-2001. The 1992 Northern Cod moratorium is marked by a vertical line in each plot, following which population decline noticeably steepened. More gradual declines started earlier, during the second half of the 1980s - when the cod fishery was stagnating as its resource was depleted, although nothing was done soon enough to avert the approaching collapse (Haedrich and Hamilton, 2000; Hamilton et al., 2004a). Roughly similar graphs, including the foreshadowing of pre-crisis declines, could be drawn for many other North Atlantic fishing regions.

$<<$ Figure 4 about here $>>$

\section{UNEVEN IMPACTS OF ENVIRONMENTAL CHANGE}

Environmental change and the resulting social response tend to have heterogeneous effects, creating winners and losers. As accessible stocks get depleted, traditional inshore fisheries are the first hurt by resource scarcity. Larger vessels ranging farther afield, or able to 
pursue different species, might still return high catches for a while, even as stocks decline. Thus, fisheries troubles reinforce and hasten macro-social shifts from labor- to capital-intensive production, and toward geographic, enterprise and individual concentration of wealth. After a collapse, government relief programs often give support proportional to recent catches, which favors the higher-capital sector. New fisheries targets such as capelin or shrimp create fresh economic opportunities - but only for those who can make the investments, and gain the licenses, to harvest them. New fisheries do not necessarily support the same people and places as the old.

Even ecosystem-scale changes can have local variations that, interacting with social factors, lead to divergent outcomes among neighboring communities. Figure 5 tracks changes in the landed values as Newfoundland's most fisheries-dependent regions experienced an ecological regime shift. Historically, demersal species (most importantly, cod) comprised most of the value. Their landings in Figure 5 show general declines punctuated by sharp drops around 1992-94, as the Northern Cod and other key fisheries closed down. After this collapse, two crustacean species became more important: snow crab and northern shrimp. These and some other invertebrates grew more abundant as predatory fish disappeared (for one analysis of the cod-shrimp correlation, see Lilly, Parsons and Kulka, 2000). Around the same time that marine ecology was shifting, there were also market changes (Apostle et al., 1998). Shrimp, crab and other invertebrates increasingly brought high prices on the new global markets, buoyed by Japanese demand and inexpensive jet fuel. Together, the ecological and market shifts allowed Newfoundland's fishing industry to substitute invertebrates for the vanishing cod.

\section{$<<$ Figure 5 about here $>>$}

The cod-to-crustaceans transition was roughly an even exchange for the economy of Newfoundland as a whole. At smaller scales we see uneven effects. Landings value on the Northern Peninsula fell and then rose again, with booming although probably unsustainable shrimp harvests in the Gulf of St. Lawrence and Labrador Sea. Notre Dame Bay landings value also increased, largely due to snow crab. South Coast and Burin Peninsula fisheries, which in the 1980s had total values similar to Notre Dame Bay, subsequently faced decline or stagnation.

One correlate of the cod-to-crustaceans transition in Figure 5 has been a growing inequality between regions, and between communities within regions (Hamilton and Butler, 2001). Capital investment, essential to the new fisheries, has been concentrated. Places with access to rich invertebrate resources, or with appropriate processing plants, had new geographical advantages. Moreover, trawling for shrimp requires a larger minimum vessel size than cod fishing. The two species consequently have different socioeconomic implications. Snow crab, which recently surpassed shrimp as Newfoundland's most valuable landed product, also have a different profile than shrimp. Crab trapping requires less investment than shrimp trawling, and crab also tends to support more processing jobs on land.

\section{CONCLUSIONS}

Social factors affect both the causes and consequences of environmental change. Prospective studies of hypothesized future climate change often pose questions of the form, How will society be affected if the environment changes thus? Retrospective studies of observed past environmental change suggest a nuanced answer: Not deterministically but in heterogeneous, dynamic ways that are filtered by social factors. The impacts of climate change upon ecosystems, for example, depends partly on human activities (such as fishing) in those systems. The impacts of climate and ecosystem change upon societies depends partly on societal 
characteristics and response. We see this clearly in the divergent paths taken by once-similar fishing communities. Some places diversify and thrive, some find new but still fragile specialties, while others fade to a shadow of their former importance. Although the prospective literature understandably emphasizes adaptation, historically we also see instances of maladaptation, or responses that made resource change worse. Technological and effort intensification, almost universal responses to resource troubles, tend to increase rates and scales of depletion.

Economic diversification presents challenges in rural areas, where transportation to markets, human capital and production costs all could be problematic. Tourism has been viewed as "Plan B" by many struggling coastal communities, but the supply of tourists is no more certain than the supply of fish. Government subsidies and other new investments are important but not sufficient aids to diversification. Unless favorable labor and market conditions exist, new investments might create no sustainable activity. Subsidies moreover get distributed unevenly through the political process, creating more winners and losers. Some communities prove more cohesive, politically effective or entrepreneurial than others, which also can help them adapt. Political aspects can be particularly important because, along with a changed marine environment, fisher folk must often adapt to a more stringent, more dominant regulatory environment as well.

\section{REFERENCES}

Ástthórsson, O.S. \& Gíslason, A. (1995). Long-term changes in zooplankton biomass in Icelandic waters in spring. ICES Journal of Marine Science 52, 657-668.

Ástthórsson, O.S. \& Gíslason, A. (1998). Environmental conditions, zooplankton, and capelin in the waters north of Iceland. ICES Journal of Marine Science 55, 808-810.

Ástthórsson, O.S., Hallgrimsson, I., \& Jonsson, G.S. (1983). Variations in zooplankton densities in Icelandic waters in spring during the years 1961-1982. Journal of the Marine Research Institute 7(2), 73-113.

Belkin, I.m., Levitus, S., Antonov, J., \& Malmberg, S-A. (1998). 'Great salinity anomalies' in the North Atlantic. Progress in Oceanography 41, 1-68.

Belkin, I.M. (2000). Decadal variability of the Greenland Ice Sheet mass balance as a cause of the 'Great Salinity Anomalies' in the northern North Atlantic. Arctic Forum-2000, Washington, DC, 12-13.

Buch, E. (2000). A Monograph on the Physical Oceanography of the Greenland Waters. Copenhagen: Danish Meteorological Institute, Scientific report 00-12.

Buch, E., Pedersen, S.A., \& Nielsen, M.H. (2001). On the coupling between climate, hydrography and recruitment variability of fishery resources off West Greenland. ICES Decadal Symposium, Edinburgh, August 8-10. 
Dickson, R.R., Meincke, J., Malmberg, S-A., \& Lee, A.J. (1988). The 'Great Salinity Anomaly' in the northern North Atlantic 1968-82. Progress in Oceanography 20, 103-151.

Drinkwater, K.F. (2002). A review of the role of climate variability in the decline of northern cod. American Fisheries Society Symposium, 32, 113-130.

Haedrich, R.L., \& Hamilton, L.C. (2000). The fall and future of Newfoundland's cod fishery. Society and Natural Resources 13, 359-372.

Hamilton, L.C., \& Otterstad, O. (1998a). Demographic change and fisheries dependence in the northern Atlantic. Human Ecology Review 5(1), 16-22.

Hamilton, L.C., \& Otterstad, O. (1998b). Sex ratio and community size: Notes from the northern Atlantic. Population and Environment 20(1), 11-22.

Hamilton, L.C., Duncan, C.M., \& Flanders, N.E. (1998). Management, adaptation and largescale environmental change. In D. Symes Property Rights and Regulatory Systems in Fisheries (pp. 17-33). Oxford: Fishing News Books.

Hamilton, L.C., Rasmussen, R.O., Flanders, N.E., \& Seyfrit, C.L. (1998). Outmigration and gender balance in Greenland. Arctic Anthropology 33(1), 89-97.

Hamilton, L.C., \& Haedrich, R.L. (1999). Ecological and population changes in fishing communities of the North Atlantic Arc. Polar Research 18(2), 383-388.

Hamilton, L.C., Lyster, P., \& Otterstad, O. (2000a). Social change, ecology and climate in 20th century Greenland. Climatic Change 47(1/2), 193-211.

Hamilton, L.C., \& Duncan, C.M. (2000b). Fisheries dependence and social change in the northern Atlantic. In D. Symes Fisheries Dependent Regions (pp. 95-105 ). Oxford: Fishing News Books.

Hamilton, L.C., \& Butler, M.J. (2001). Outport adaptations: Social indicators through Newfoundland's cod crisis. Human Ecology Review 8(2), 1-11.

Hamilton, L.C., Brown, B.C., \& Rasmussen, R.O. (2003). West Greenland's cod-to-shrimp transition: Local dimensions of climatic change. Arctic 56(3), 271-282.

Hamilton, L.C., Haedrich, R.L., \& Duncan, C.M. (2004a). Above and below the water: Social/ecological transformation in northwest Newfoundland. Population and Environment 25(3), 195-215.

Hamilton, L.C., Jónsson, S., Ögmundardóttir, H. \& Belkin, I.M. (2004b). Sea changes ashore: The ocean and Iceland's herring capital. Arctic 57(4), 326-336. 
Hamilton, L.C., Colocousis, C.R., \& Johansen, S.T.F. (2004c). Migration from resource depletion: The case of the Faroe Islands. Society and Natural Resources 17(5), 443-453.

Hamilton, L.C., Otterstad, O., and Ögmundardóttir, H. (forthcoming-a). Rise and fall of the herring towns: Impacts of climate and human teleconnections. In S.F. Herrick Jr., M. Barange and R. Hannesson Climate Change and the Economics of the World's Fisheries. Northampton MA: Edward Elgar.

Hamilton, L.C. (forthcoming-b). The human dimensions: Demographic impacts of fisheries decline. In K. Drinkwater and K. Brander, Cod in a Changing Climate. Springer.

ICES (2001). Report of the ICES Advisory Committee on Fisheries Management (ICES Cooperative Research Report No. 246). Copenhagen: ICES.

ICES (2005). International Council for the Exploration of the Sea Web site. http://www.ices.dk/indexfla.asp

NAFO (2005). Northwest Atlantic Fisheries Organization Web site. http://www.nafo.ca/

Palmer, C. T., \& Sinclair, P. R. (1997). When the Fish Are Gone: Ecological Disaster and Fishers in Northwest Newfoundland. Halifax, NS: Fernwood Publishing.

Pauly, D., Christensen, V., Dalsgaard, J., Froese, R., \& Torres, F. Jr. (1998). Fishing down marine food webs. Science, 279, 860-863.

Rasmussen, R.O., \& Hamilton, L.C. (2001). The Development of Fisheries in Greenland, with Special Focus on Paamiut/Frederikshab and Sisimiut/Holsteinsborg. Roskilde, Denmark: North Atlantic Regional Studies.

Rätz, H-J. (1992). Decrease in fish biomass off West Greenland (subdivisions 1B-1F). NAFO SCR Doc 92/40.

Rätz, H-J. (1999). Structures and changes of the demersal fish assemblage off Greenland, 1982-96. NAFO SCR 32, 1-15.

Sinclair, A. F., \& Murawski, S. A. (1997). Why have groundfish stocks declined? In J. Boreman, B. S. Nakashima, J. A. Wilson, \& R. L. Kendall (Eds.), Northwest Atlantic Groundfish: Perspectives on a Fishery Collapse (pp. 71-93). Bethesda MD: American Fisheries Society.

Thórdardóttir, Th. (1977). Primary production in North Icelandic waters in relation to recent climatic change. Pp. 655-665 in M.J. Dunbar (Ed.) Polar Oceans. Proceedings of the Polar Oceans Conference held at McGill University, Montreal, 1974. Arct. Inst. Amer., Canada. 
Vilhjálmsson, H. (1997). Climatic variations and some examples of their effects on the marine ecology of Icelandic and Greenlandic waters, in particular during the present century. Journal of the Marine Research Institute 15(1), 9-29. 


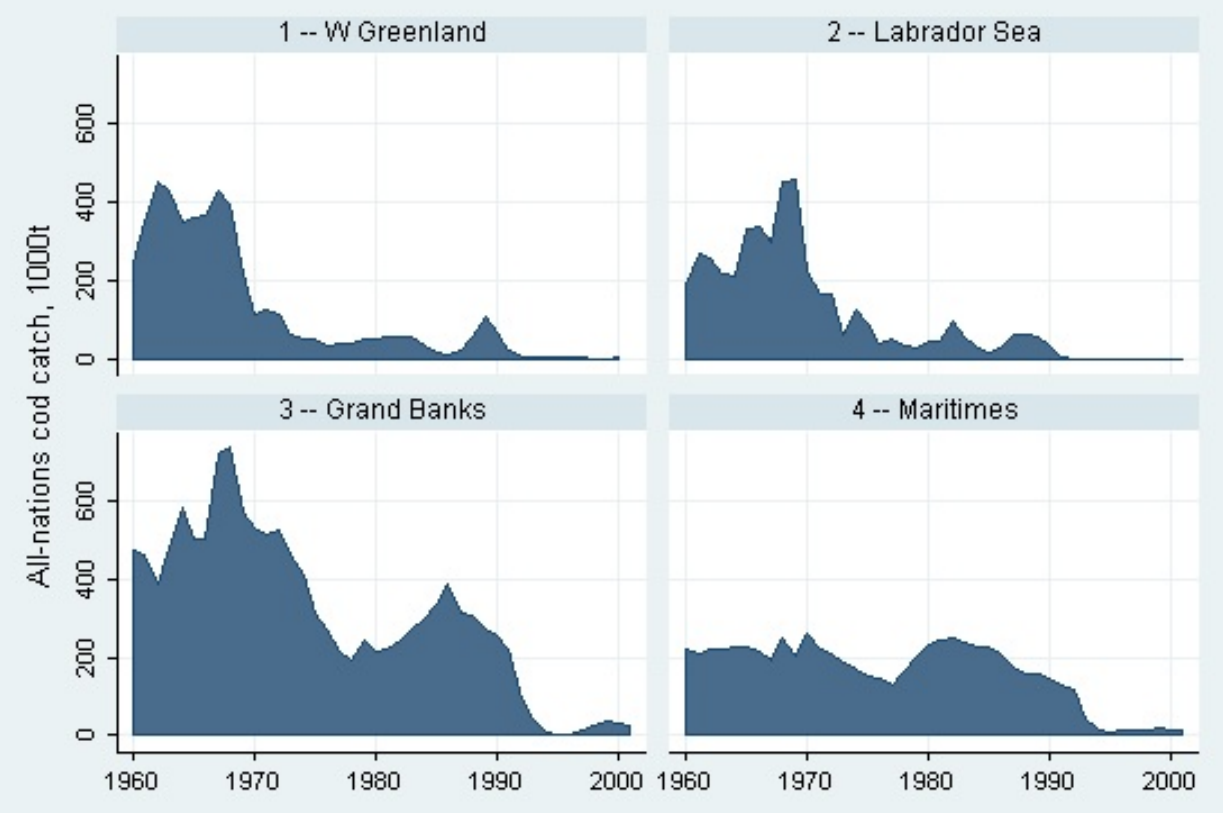

Figure 1: Cod catch in four Northwest Atlantic regions, 1960-2001. The regions correspond to NAFO statistical divisions 1 through 4. Data source: NAFO 2005.

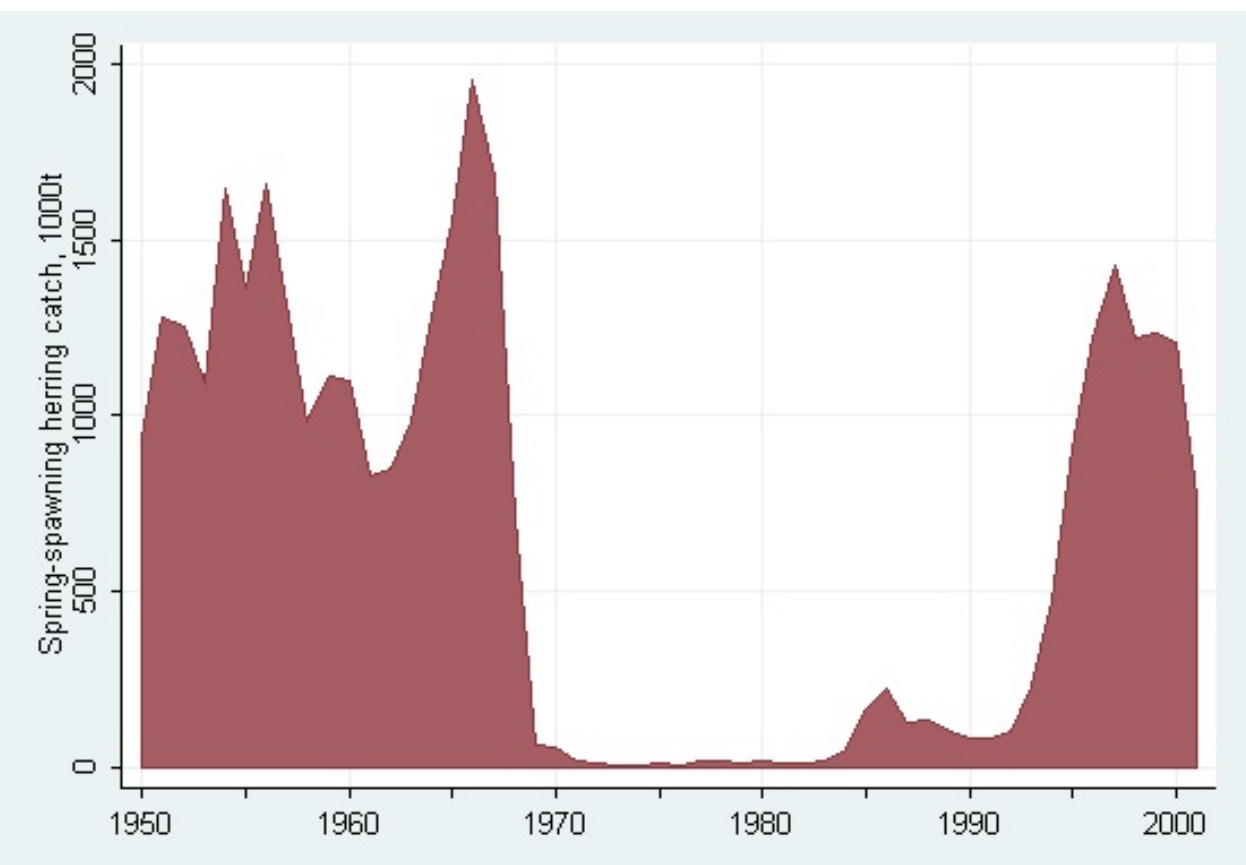

Figure 2: Total catch of Norwegian spring-spawning herring, 1950-2001. Data source: ICES 2001. 


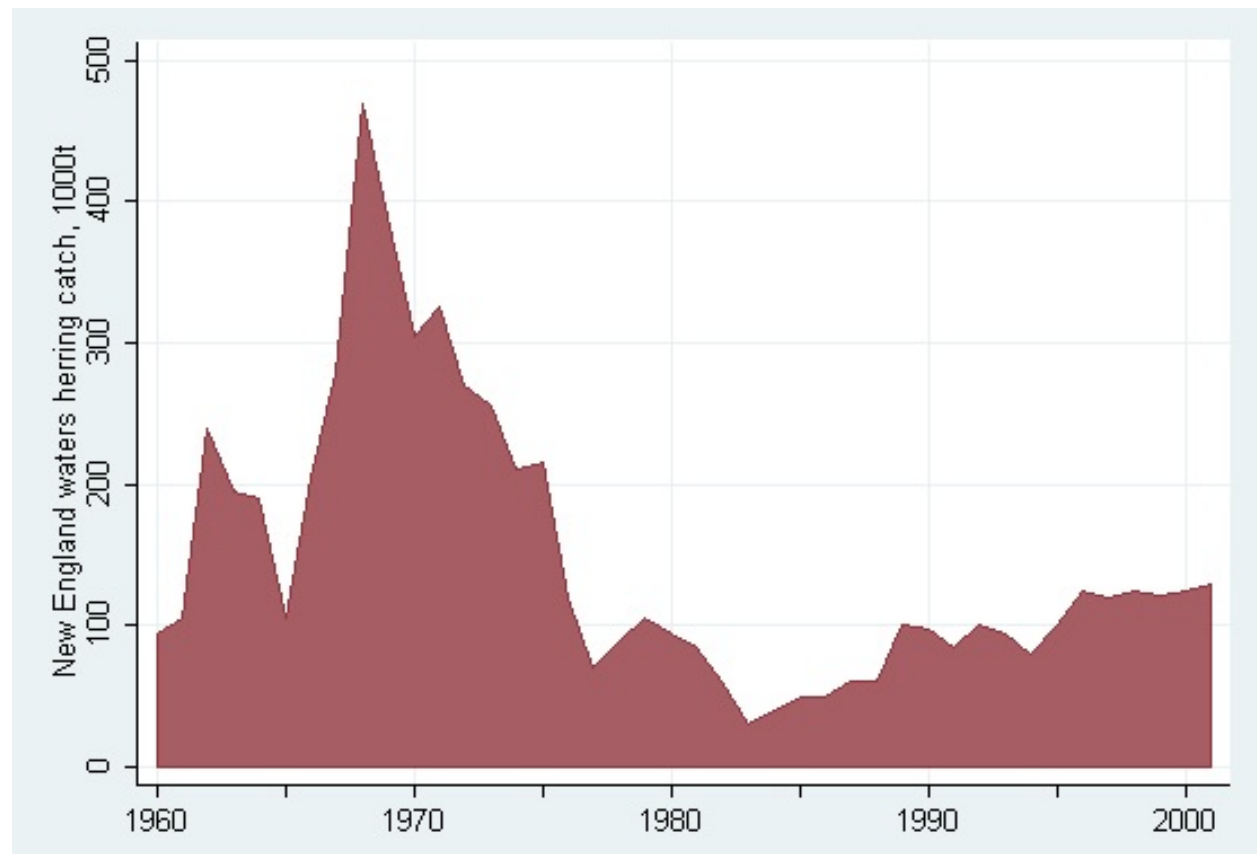

Figure 3: Total catch of herring in New England waters, 1960-2001. Data source: NOAA.
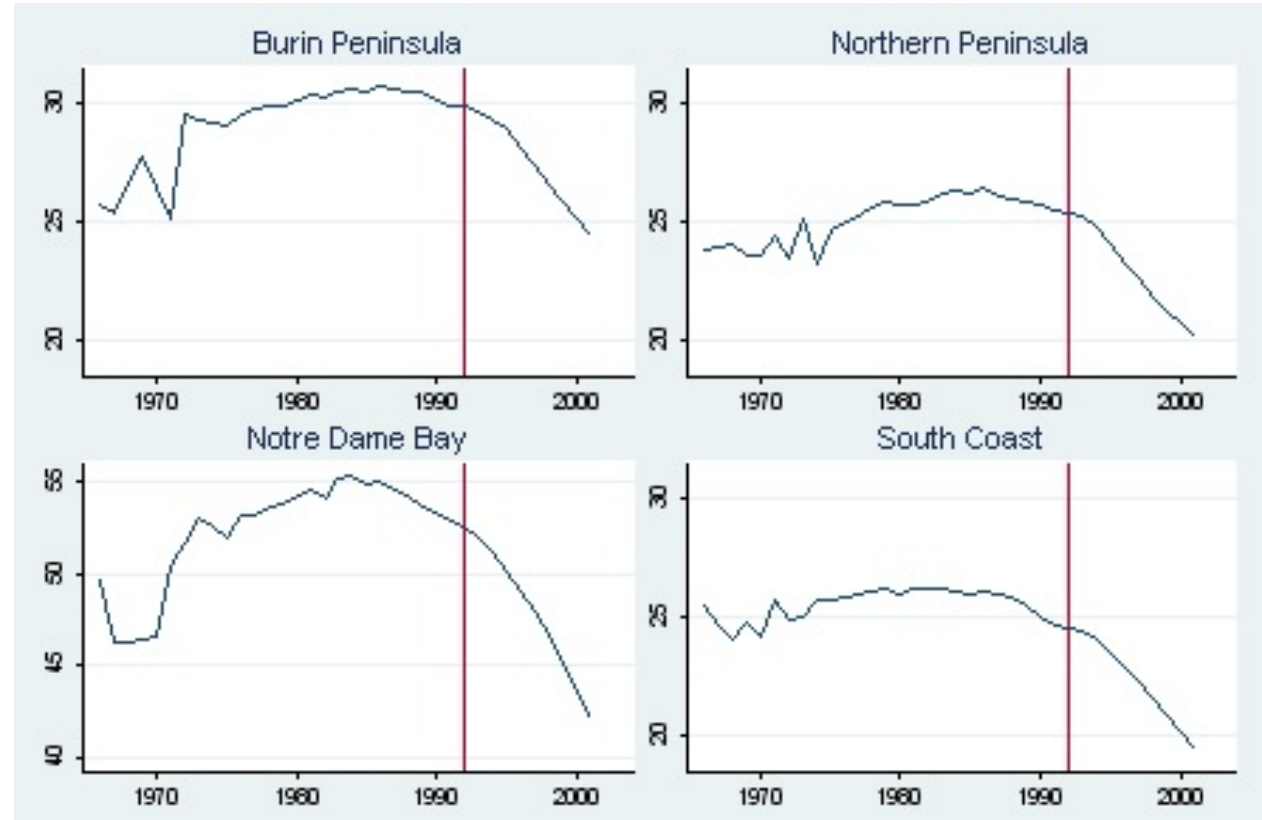

Figure 4: Population in thousands for the four most fisheries-dependent regions in Newfoundland, 1966-2001. Note the individual $y$-axis scales. Updated from Hamilton and Butler, 2001. 


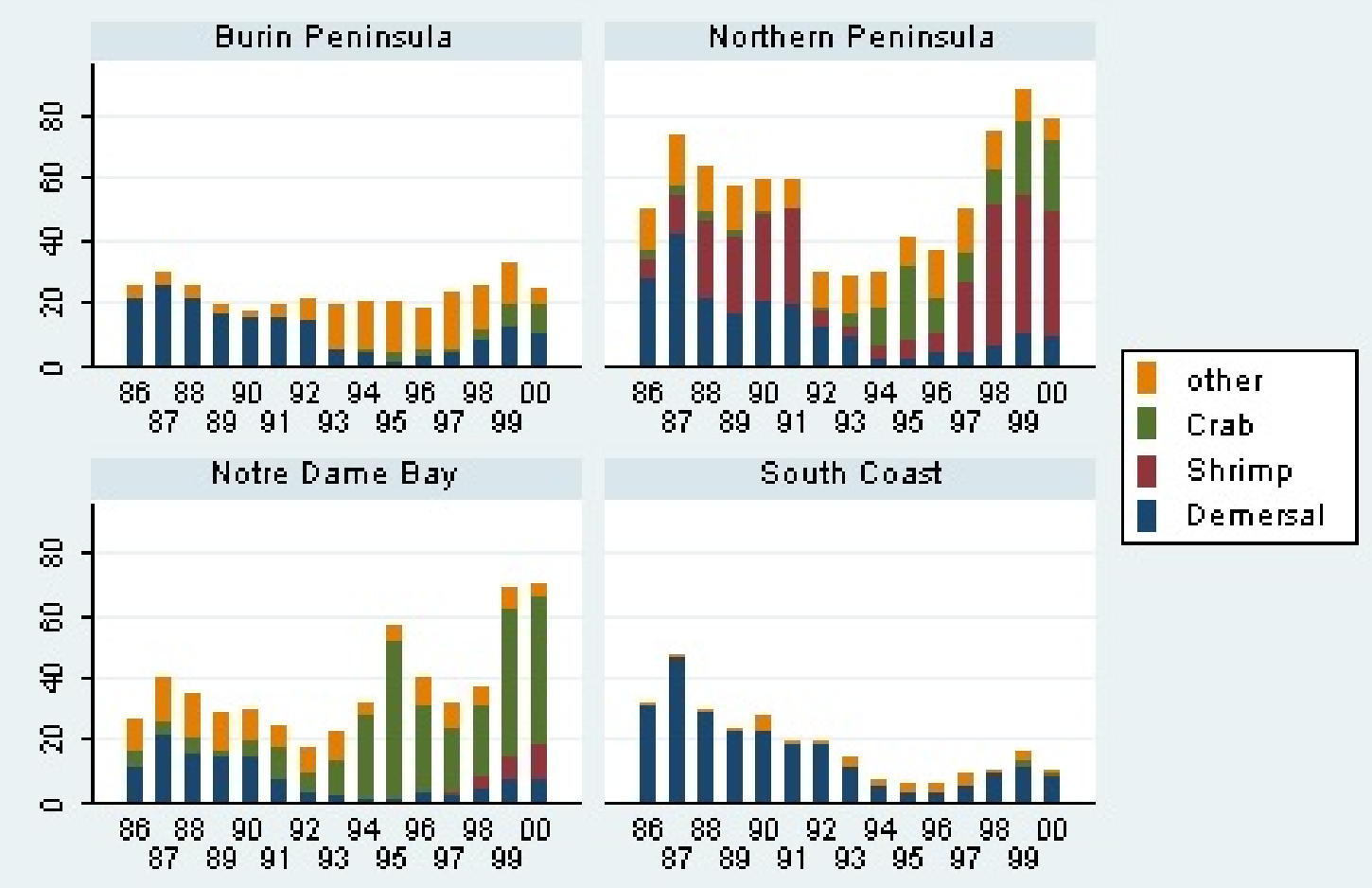

Figure 5: Landed value (millions of 2000 Canadian dollars) by species type in Newfoundland's most fisheries-dependent regions, 1986-2000. Adapted from Hamilton and Butler, 2001. 